\title{
COMPANY IN CRISIS
}

This paper deals with corporate crisis. It draws attention to the failing firm strategy in times of crisis. The corporate crisis is an important part of business life cycle. Proper crisis management is necessary for the survival of a competitive fight and staying on the market.

Keywords: crisis, strategy, redevelopment, restructuring, competition, performance.

\section{Introduction}

The current period is characterized by many changes. Constantly creating new products, new markets bring new opportunities but also threats. Each company tries to cope with the competitive environment and deliver the best possible competitive position. For success in business areas is not enough to accurately know business' environment. The understanding of internal processes is crucial to maintain a successful operation on the market. Measurement of corporate performance can be seen as a key factor in achieving a stable position in the market and gaining competitive advantage. Analyses of selected indicators help managers make good decisions with full knowledge of each other.

Achieved business results are diverse in market environment. Business success is contingent upon the choice and implementation of strategies for maintaining and growth of competitiveness. An appropriately chosen strategy leads to the proper direction of the company, or, at the time of corporate crisis to save the company itself.

Detailed analysis of corporate performance can determine the situation, the company is in.

According to Fig. 1 three main states of the organization have been generated:

- a company with a favorable state of performance,

- a company with less favorable state of performance,

- a company with poor results in performance.

\section{Company with a favorable state of performance}

The business environment is constantly faced with competing and fighting with a commitment to stay on the market. Company performance based on in-depth analysis is finding favorable situation a positive sign of the strategic actions of the management. To

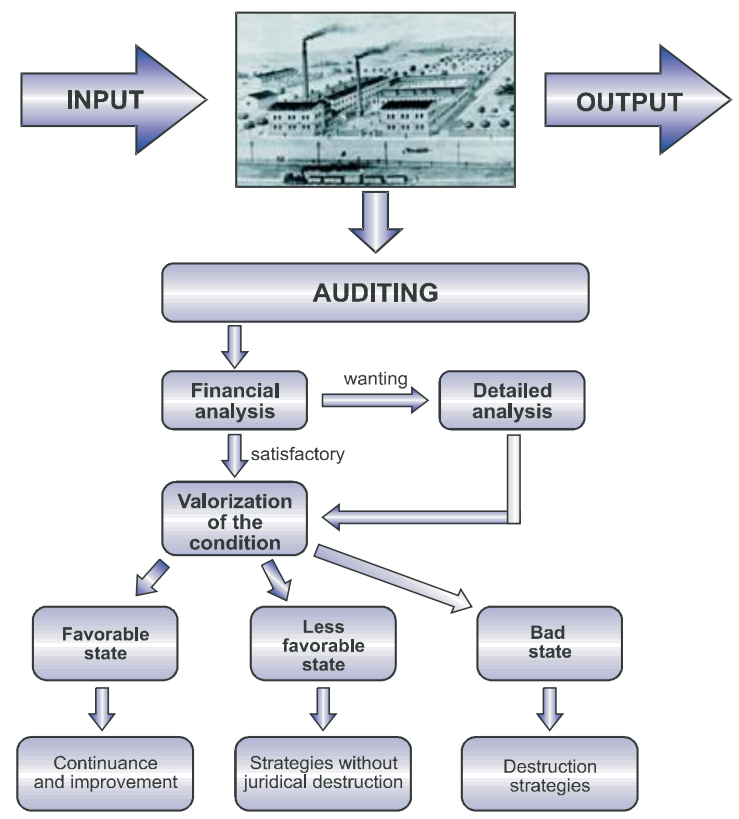

Fig. 1 Scheme of the decision [3]

maintain and to improve achieved state it is necessary to continue in process and strategic decisions improvement, which relates to enterprise focus, changes of range, markets, technologies, capacity and resources. As Blasko [3] introduces, one of the possible ways how to ensure the effective course of the enterprise in a changing competitive environment, is the management based on an appropriate forecasting of future activities in the long time terms. He designed a supportive decision-making system that was developed for the managers and is one of the crucial systems supporting good decisions making. The structure of the system provides a good set of tools for creating and evaluating potential alternative solutions of real situations.

\footnotetext{
* Lucia Vrablova, Milan Gregor,

Department of Industrial Engineering, Faculty of Mechanical Engineering, University of Zilina, Slovakia, E-mail: lucia.vrablova@fstroj.uniza.sk
} 


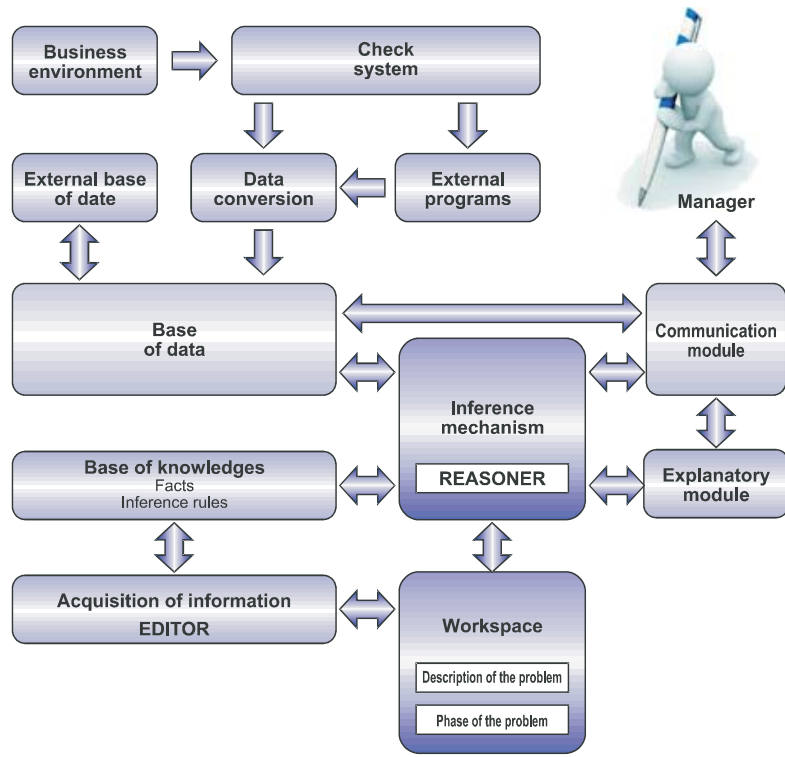

Fig. 2 Scheme of the decision (according to [3])

This model can be recommended for firms situated in the good values of corporate performance. The system allows a quick and effective monitoring of the production and economic activities and their multilateralism enables making of strategic decisions aimed at the maintaining and improving the current situation [3].

\section{Enterprise with less favorable state of performance}

There is a significant number of companies going into bankruptcy from day to day, but it is a longer process, during which certain characteristics and phases can be monitored. As Synek [1] introduces, for the first phase of business crisis is mainly typical decrease of performance. In the second phase decrease of profitability follows, the next phase is characterized by increased working

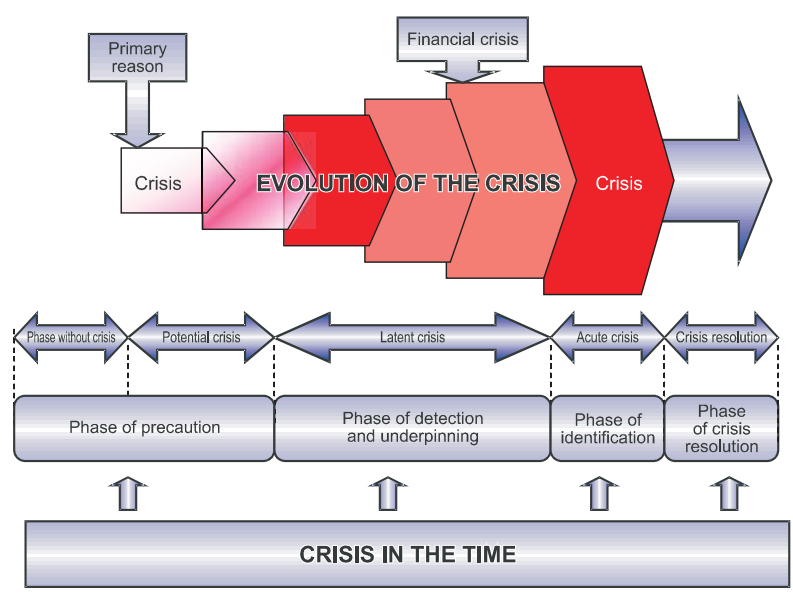

Fig. 3 Crisis at the time [2] capital need, and in the fourth phase the adjustment of capital structure is failing. In the last phase the company denotes insolvency hence lack of liquidity of the company. In order to take various measures, it is necessary to determine the specific case-history of the company, hence identification of the causes, nature and development stage of the crisis.

Zivcak [2] characterized predicamental enterprise's development as a time series of predicamental conditions obtaining a continuous nature and, to a large extent, representing predetermined orientation of their next movement at the time.

The crisis formation is subject to causes which can be divided into internal and external. It is possible to affect internal causes by permanent analyses and evaluations within a company. These causes are, for example, decreasing outputs, liquidity problems, reducing of profit margins etc.. More complicated situation is when crisis arises because of external factors. In such a case, there are certainly factors which company cannot affect, but their influence has a major impact on the overall economic situation. Such factors include economic factors (such as life-cycle phase), financial (development of financial market instruments), or monetary factors (changes in interest rates).

The second step is needed to define the nature of the crisis, whether it is a strategic crisis, crisis caused by economic results, or a liquidity crisis. Strategic crisis is a crisis caused by wrong strategic decisions, such as improper allocation of areas of business, improperly selected portfolio of products, or investment strategy which causes excessive production capacity. Causes of the crisis created by the action of profit are high prices with respect to the absorption ability of the market, high personnel costs, and errors in business financing, or inappropriate target of investment. The liquidity crisis is usually caused by prolonged violation of fundamental rules of financial balance, a low level of receivables and inventory management care, or large investments in excess of the company ability [2].

The most common symptoms that can be seen when the company is in the state of threat are the loss of liquidity, a temporary decrease in sales, or excessively high gearing ratio. If early detection of threats state is done, strong likelihood of right corrective arrangements or survival strategies exists. The task of the survival strategies is to ensure existence of a company and prevent the possible extinction.

Enterprise located in a state of emergency may be managed using the survival strategies without the legal and property extinction of enterprise.

Basic survival strategies without possibility of legal and property extinction of a company include:

- Consolidation - is the act of merging many things into one. In business, it often refers to the mergers and acquisitions of many smaller companies into much larger ones. In the context of financial accounting, consolidation refers to the aggregation of financial statements of a group company as consolidated financial 
statements. We see IBM, Oracle and Microsoft buying up either specialty companies to fill out their portfolios, to get certain people in the fold, or to remove the competition.

- Restructuring is the termination of employees and reorganization of those remaining; it can include reductions in plant and equipment. Restructuring is usually implemented to realize cost savings. Quite often financial restructuring is used. Financial restructuring is a process geared at avoiding the liquidation of the company. Usually it involves agreement by third parties to satisfy creditors' claims under certain terms and conditions. Financial restructuring may also be carried out by concluding an agreement with all creditors of the company under which creditors will be paid on somewhat different terms than those initially accepted by the company when credit and loans were extended. This form of financial restructuring enables the company to continue its operations and minimize creditors' losses.

- Reengineering is a management tool that became popular in the late 1980s and early 1990s. Like many such tools, it aims to cut costs while at the same time increase productivity and provide higher levels of service. And while all this is true, reengineering still offers companies much more. The concept that is at the heart of all reengineering projects is the need to stay competitive in today's business world, and this broad concept involves costs, quality, productivity, and a host of other business elements.

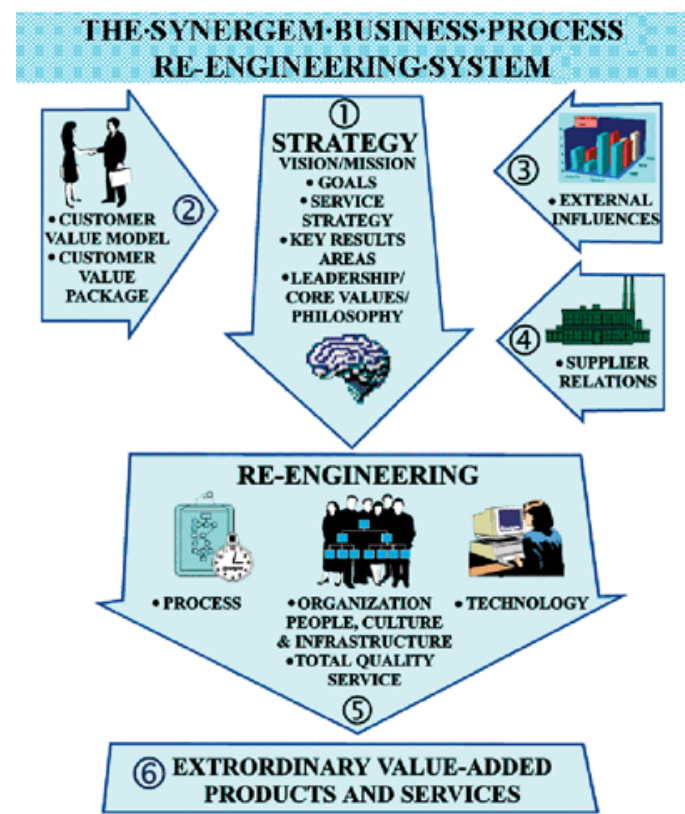

Fig. 4 Re - engineering process

- Rehabilitation is a restoration of an entity to its normal or nearnormal functional capabilities after the occurrence of a disabling event.

- Management based on control contract includes negotiating the terms and conditions in contracts and ensuring compliance with the terms and conditions, as well as documenting and agreeing on any changes that may arise during its implementation or execution. It can be summarized as the process of systematically and efficiently managing contract creation, execution, and analysis for the purpose of maximizing financial and operational performance and minimizing risk.

\section{A company with poor results in performance}

Business solution of the crisis may be a strategy with the legal dissolution of the company. Such approaches are used in a situation when it is no longer possible to apply the above - mentioned reorganization strategies of a company. This group includes:

- Business Transformation is a change management strategy which has the aim to align People, Process and Technology initiatives of a company more closely with its business strategy and vision. In turn this helps to support and innovate new business strategies. Transformation and change is a critical issue for most organizations. Research shows that the failure rate of change programmes at $70-80 \%$, many organizations are struggling.

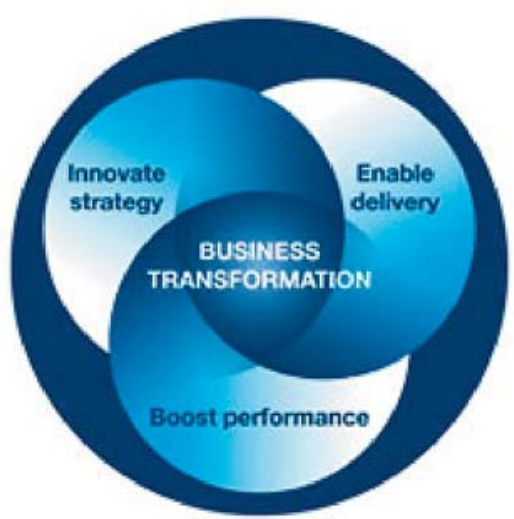

Fig. 5 Business Transformation

- Merger could be characterized as a combination of two or more separate entities for which a typical issue of securities.

- The acquisition occurs when one company buys shares in another company. In terms of the transaction, the target entity is clearly marked with the buyer, seller and the structure as well. For example the entity that is subject of purchase.

The currently ongoing wave of mergers, acquisitions and alliances in the world is very important to avoid difficulties which often manifest themselves after the merger partners. It is possible to establish a total of 12 conditions for the successful completion of the merger.

1. Strategic partners harmony - there must be a fundamental compatibility of products, markets and strategies and the harmony of the corporate culture cannot be forgotten.

2. Prevent leaks - there is often the case, especially if the result of prematurely disclosed to the media. 
3. Active management and board - requires the utmost care and management of the entire merger process.

4. Involvement brightest personalities.

5. No one may be the audience - each member of its management whose project must assume a specific role.

6. Clearly and precisely formulated vision - being a clear framework and direction of negotiations.

7. All measures implemented quickly - so the process was completed within 2-3 years. Priority should be measures with farreaching effects.

8. Clearly defined priorities - and gradually increase the complexity and complexity of merging organizations.

9. Each step proved to be clear and concise.

10. Content integration process must be transparent - in order to achieve synergies.

11. One non-bureaucratic - joining the two businesses is a good opportunity to remove obsolete organizational structures and working practices.

12. Keep the main goal - for each merger, more growth, better profitability and improved market position for the company is allowed.

\section{Conclusion}

Managerial decision making is a complex issue whose consequences are wide and directly affect the entire enterprise. Only detailed knowledge of internal links within an organization helps managers to make good decisions. Currently, after the economic crisis, many companies found themselves in an unfavorable financial situation, especially business on the brink of crisis. Crisis solution is possible by various strategies, either with a change of property and legal form, or destructive policies. Properly chosen strategy helps the company to gain a market position and continue in struggling in a competitive environment.

\section{Acknowledgement}

This paper was made about research work support: VEGA no. $10417 / 09$

\section{References}

[1] SYNEK, M.: Restrukturalizace a revitalizace ceskych podniku [Restructuring and Revitalization of the Czech Companies]. In: Mezinarodni konference „Ekonomika firem 2001, PHF EU Kosice : Svit, 2001, pp. 672-677, ISBN 80-225-1446-2.

[2] ZIVCAK, J.: Navrh modelu komplexneho procesu konkurzneho konania vyrobnej organizacie [Design Model of a Complex Process of Bankruptcy Proceedings Producer Organization]. Dissertation thesis, Zilinska univerzita, Strojnicka fakulta, Katedra priemyselneho inzinierstva, 2009, p. 132.

[3] BLASKO, S.: Navrh systemu pre podporu rozhodovania manazera v maloseriovej vyrobe [System Design for Decision Support Manager in Small Series Production]. Dissertation thesis, Zilinska univerzita, Strojnicka fakulta, Katedra priemyselneho inzinierstva, 2009, p. 135.

[4] GREGOR, M., MICIETA, B.: Produktivita a Inovacie - 1. vyd. [Productivity and Innovations - part I], Zilina : Slovenske centrum produktivity, 2010, p. 311, ISBN 978-80-89-16-5.

[5] COOL, K.: Restructuring Strategies. Bleckwell Publishing, 2005, ISBN 1405126019. 